\title{
APPLICABILITY OF NEPA'S IMPACT STATEMENT REQUIREMENT TO THE EPA
}

\section{INTRODUCTION}

Two recent decisions by the Court of Appeals for the District of Columbia Circuit have established a narrow exemption from the requirements of the National Environmental Policy Act (NEPA) ${ }^{1}$ for certain regulatory activities of the Environmental Protection Agency (EPA). ${ }^{2}$ In Portland Cement Association v. Ruckelshaus ${ }^{3}$ the court held that the EPA is not required to file an environmental impact statement under NEPA prior to promulgating stationary source air pollution standards for new or modified portland cement plants pursuant to section 111 of the Clean Air Act. ${ }^{4}$ In March 1971 the Ad-

1. 42 U.S.C. $\$ \$ 4321$ et seq. (1970). Section 102(2)(C) of NEPA prescribes that an impact statement shall consist of a "detailed statement" on

(i) the environmental impact of the proposed action,

(ii) any adverse environmental effects which cannot be avoided should the proposal be implemented,

(iii) alternatives to the proposed action,

(iv) the relationship between local short-term uses of man's environment and the maintenance and enhancement of long-term productivity, and

(v) any irreversible and irretrievable commitments of resources which would be imvolved in the proposed action should it be implemented. 42 U.S.C. $\$ 4332$ (2) (C) (1970).

The Council on Environmental Quality (CEQ), the entity having primary responsibility for advising the executive on matters concerning environmental protection, see notes 31-33 infra and accompanying text, has issued advisory guidelines for the various agencies to follow in the preparation of impact statements. CEQ GUIDELINEs, 38 Fed. Reg. 20,550 (1973). For a thorough discussion of the general subject of the preparation and content of impact statements, see F. ANDERSon, NEPA IN THE COURTS 179-245 (1973).

HEREAFTER THE FOLLOWING CITATION WILL BE USED IN THIS NOTE:

F. ANDERson, NEPA IN THE COURTs (1973) [hereinafter cited as ANDERson].

2. The EPA was created by Reorganization Plan No. 3 of 1970. 35 Fed. Reg. 15,623 (1970). See note 24 infra. The purpose of the new agency was explained by the President as that of inaking a coordinated attack on the whole range of cnvironmental problems. Message of the President, July 9, 1970, reprinted at 42 U.S.C. $\S$ 4321 note, at 10,661. Describing the EPA as a "strong, independent agency," the President expressed the intention that the EPA focus on setting and enforcing pollution control standards, rather than serving in a completely advisory capacity in inatters of environmental policy as does the CEQ. Id. at 10,661, 10,663. See notes 24,32 infra and accompanying text.

3. 486 F.2d 375 (D.C. Cir. 1973), petition for cert. filed, 42 U.S.L.W. 3388 (U.S. Jan. 8, 1974) (No. 73-1008).

4. 42 U.S.C. $\S 1857 c-6$ (1970). This provision of the Clean Air Act directs the Administrator of the EPA to designate categories of stationary sources which "may contribute significantly to air pollution which causes or contributes to the endangerment 
ministrator of the $\mathrm{EPA}^{5}$ designated portland cement plants as a stationary source of air pollution ${ }^{6}$ and in December 1971 issued standards of performance for the emission of pollutants froin these sources. ${ }^{7}$ The Portland Cement Association challenged the validity of these standards on the grounds that, inter alia, the Administrator had failed to file an environmental impact statement as required by NEPA. Concluding that section 111 of the Clean Air Act requires the EPA to compile the "functional equivalent" of a NEPA impact statement when setting emission standards, the Portland court held that the EPA is not required to comply with NEPA in establishing standards pursuant to that section. ${ }^{8}$ In a subsequent case, Environmental Defense Fund, Inc. v. EPA, ${ }^{\circ}$ the District of Columbia Circuit further held that the EPA is not required to file an environmental impact statement to justify the cancellation of the registration of a pesticide pursuant to the Federal Insecticide, Fungicide, and Rodenticide Act (FIFRA). ${ }^{10}$ The case concerned challenges to the EPA's cancellation of all registrations for the use of DDT, except for limited public health and agricultural pest quarantine purposes.11 The court found that FIFRA, like section 111 of the Clean Air Act, requires the "functional equivalent" of a NEPA statement prior to cancellation of a registration stateinent, inasinuch as it provides sufficient substantive and procedural standards to ensure adequate consideration of environmental issues. ${ }^{12}$

of public health or welfare," and to promulgate standards of performance for these categories. Id. $\$ 6(\mathrm{~b})(1)(\mathrm{a})$.

5. The Administrator of the EPA is designated as head of the agency by section 1(b) of the Reorganization Plan No. 3 of 1970. 35 Fed. Reg. 15,623 (1970). See note 24 infra.

6. 36 Fed. Reg. 5931 (1971).

7. 40 C.F.R. $\$ 60.60$ (1973).

8. Portland Cement Ass'n v. Ruckelshaus, 486 F.2d 375, 384 (D.C. Cir. 1973). See also Essex Chemical Corp. v. Ruckelshaus, 486 F.2d 427, 431 (D.C. Cir. 1973), cert. denied, 42 U.S.L.W. 3610 (U.S. Apr. 29, 1974).

9. 489 F.2d 1247 (D.C. Cir. 1973).

10. 7 U.S.C. $\$ \S 135-135 \mathrm{k}$ (1970). The purpose of FIFRA is to require the registration of every ecouomic poison distributed or sold in the United States. The Administrator's primary functions under FIFRA are to consider applications for the registration of economic poisons and to determine if registered econoinic poisons should be cancelled or suspended. Id. $\$ 135 \mathrm{~b}$ (1970). An order of the Administrator cancelling a registration must set forth detailed findings of fact and must be based on substautial evidence developed at a liearing, if a public learing is held. $I d . \S 135 \mathrm{~b}$ (c) (1970). The Administrator of the EPA acquired the authority to administer the act pursuant to Reorganizatiou Plan No. 3 of 1970. See note 24 infra.

11. 489 F.2d at 1249. The Euvironmeutal Defense Fuud contended that the EPA should lave banned all uses of DDT. On the other hand, Coahoma Chemical Company and other DDT producers and users challenged the cancellation order as going too far. Id.

12. Id. at $1256-57$. 
Consequently, the court held that, in actions taken pursuant to FIFRA, the EPA was excused from strict complance with the impact statement requirements of NEPA. ${ }^{13}$

\section{Origin of the Problem}

\section{NEPA's Ambiguous Legislative History}

As its name implies, NEPA declares a national policy to "encourage productive and enjoyable larmony between man and his environment . . . . "14 To assure the effective implementation of this policy, section 102(2)(C) of NEPA requires all agencies of the federal government, to the fullest extent possible, to file an environmental impact statement prior to embarking upon "major Federal actions significantly affecting the quality of the luman environment . . . ."15 However, despite the plain language of section $102(2)(C)$, the legislative history of the Act raises doubts as to whether Congress intended NEPA's impact stateinent requirement to apply to those agencies that were already charged with environmental protection responsibility at the time NEPA was enacted. While neither NEPA itself nor the Committee reports expressly exempt regulatory agencies bearing soine responsibility for environmental protection, ${ }^{16}$ such an exemption is suggested by language in a document entitled "Major Changes in S. 1075 as passed by the Senate," which Senator Jackson placed into the Congressional Record during the Senate debate on NEPA immediately prior to adoption of the final Conference Report on the Act. This document stated that section 102 of NEPA was "not desigued to result in any change in the manner in which [those agencies with prior authority for environmental protection] carry out [that] authority."117 Senator Muskie also joined in the debate at this point to underscore the fact that it

13. Id. at 1257 .

14. 42 U.S.C. $\S 4321$ (1970).

15. 42 U.S.C. $\S 4332(2)(C)(1970)$. For a discussion of what constitutes a "major" federal action "significantly affecting the quality of the human environment," see ANDERSON 73-105.

It should be noted that, while the impact statement requirement has stimulated the most litigation and public discussion, it is not the only "action-forcing" provision of NEPA. See id. at 3.

16. Portland Cement Ass'n v. Ruckelshaus, 486 F.2d 375, 381 (D.C. Cir. 1973); see S. REP. No. 296, 91st Cong., 1st Sess. (1969); H.R. REP. No. 765, 91st Cong., 1st Sess. (1969).

17. 115 Cong. Rec. $40,417,40,418$ (1969). The document further stated that

[t]his provision is, however, clearly designed to assure consideration of environmental matters by all agencies in their planning and decision makingespecially those agencies who now have little or no legislative authority to take environmental considerations into account. Id. 
was his "clear understanding" that the legislative mandates of those agencies were not changed in any way. ${ }^{18}$ In the House of Representatives, Congressman Dingell, the House sponsor of the Act, inserted a similar statement of interpretation into the record. ${ }^{10}$ However, neither the final Conference Report on the Act nor the section-bysection analysis of NEPA embodied in that report imcludes an exemption for such agencies. ${ }^{20}$ Thus, while the views of Senators Jackson and Muskie, the senatorial sponsors of NEPA, are entitled to some weight, ${ }^{21}$ there is general agreenent that the legislative history of NEPA is inconclusive as to the applicability of the impact statement requirement of NEPA to environmental agencies. ${ }^{22}$

\section{Application of NEPA to the New Agency}

Even if congressional intent were clear as to the applicability of NEPA to the agencies already vested with environmental protection responsibility when the Act was passed, the applicability of NEPA's environmental impact statement requirement to the EPA is even further obfuscated by the fact that the EPA was not then even in existence. NEPA was enacted by Congress in late 1969, whereas the creation of the EPA did not come about until almost one year later in Deceinber $1970 .^{23}$ Moreover, the EPA was not created by an act

18. Id. at 40,423 .

19. Id. at 40,925. Congressman Dingell's remarks were in the form of answers to questions submitted to him by Congressman Fallon, Chairman of the House Committee on Public Works. The specific question asked was what would be the effect of the legislation on the Federal Water Pollution Control Agency (a predecessor of the EPA). The answer, in part, was as follows:

Many existing agencies .... already have important responsibilities in the area of environmeut control. The provisions of Sections 102 and 103 are not designed to result in any change in the manner in which they carry out their environmental protection anthority. Id.

20. H.R. ReP. No. 765, 91st Cong., 1st Sess. 7 (1969), reprinted in U.S. CoDE Cong. \& AD. News 2767, $2769-70$ (1969). See also 115 Cong. REc. 40,422 (1969) (remarks of Senator Allott).

21. Senator Jackson was sponsor of S. 1075, the original Senate version of NEPA, and chaired the Senate Committee on Interior and Insular Affairs, which considered the bill. ANDERSON 5. He also acted as floor manager for the Conference Report. Senator Muskie was Chairman of the Subcommittee on Air Pollution of the Committee on Public Works. Id. See also Portland Cement Ass'n v. Ruckelshaus, 486 F.2d 375, 381 n.24 (D.C. Cir. 1973).

22. See, e.g., Portiand Cement Ass'n v. Ruckelshaus, 486 F.2d 375, 383 (D.C. Cir. 1973); Comment, Halfway There: EPA's "Environmental Explanations" and the Duty to File Impact Statements, 3 ENvIRONmeNTAL L. REP. 10,139, 10,140 n.2 (1972); 1973 DUKE L.J. 347, 350, in 1972 Developments.

23. The conference report was agreed to by the Senate on December 20, 1969, 115 CoNG. REC. 40,415-27 (1969), and the House on December 23, 1969, id. at 40,92328. NEPA became effective on January 1, 1970. 42 U.S.C. $\$ 4321$ (1970). 
of Congress, but by the President's exercising his powers of agency reorganization in order to transfer the federal government's then widely dispersed environmental protection functions to one centralized agency. $^{24}$ It is obviously more than moderately difficult to infer from such an executive action any congressional intent regarding the applicability of NEPA to the new agency. Thus, even had Congress intended NEPA's impact statement requirement to apply to those agencies which bore some type of environmental protection responsibility when the Act was passed, it by no means necessarily follows that Congress would have also intended that NEPA apply to the new centralized agency whose sole task is the preservation and protection of the environment. ${ }^{25}$

The EPA came into being on December 2, 1970. See Message of the President, July 9, 1970, reprinted at 42 U.S.C. $\$ 4321$ note, at 10,659.

24. The EPA was created by Reorganization Plan No. 3 of 1970, 35 Fed. Reg. 15,623 (1970), which was prepared by the President and transmitted to the Congress on July 9, 1970, pursuant to 5 U.S.C. $\$ \$ 901$ et seq. (1970). This statute permits such a reorganization "to promote the better execution of the laws, the more cffective managemeut of the executive branch and of its agencies and functions, and the expeditious administration of the public business," $i d$. $\$$ 901(a)(1), and "to imcrease the efficiency of the operations of the Government to the fullest extent practicable," id. § 901 (a) (3). See also Message of the President, July 9, 1970, reprinted at 42 U.S.C. $\S$ 4321 note, at 10,661 .

The functions transferred to the Administrator of the EPA under Reorganization Plan No. 3 include:

-The functions carried out by the Federal Water Quality Administration (from the Department of the Interior).

-Fuuctions with respect to pesticides studies now vested in the Department of the Interior.

-The functions carried out by the National Air Pollution Control Administration (from the Department of Health, Education and Welfare).

- The functions carried out by the Bureau of Solid Waste Management and the Bureau of Water Hygiene, and portions of the functions carried out by the $\mathrm{Bu}$ reau of Radiological Health of the Environmental Control Admimistration (from the Department of Health, Education and Welfare).

- Certain functions with respect to pesticides carried out by the Food and Drug Administration (from the Department of Health, Education and Welfare).

-Authority to perform studies relating to ecological systems now vested in the Council on Environmental Quality.

- Certain functions respecting radiation criteria and standards now vested in the Atomic Energy Commission and the Federal Radiation Council.

-Functions respecting pesticides registration and related activities now carried out by the Agricultural Research Service (from the Department of Agriculture). Message of the President, July 9, 1970, reprinted at 42 U.S.C. $\$ 4321$ note, at 10,661-62.

See 1973 Duke L.J. 347, 351 n.26, in 1972 Developments.

25. Portland Cement Ass'n v. Ruckelshaus, 486 F.2d 375, 380 (D.C. Cir. 1973). For treatment of the question of NEPA's applicability to the EPA by other commeutators, see Comment, Implementation of the Clean Air Act: Should NEPA Apply to the Environmental Protection Agency?, 3 EcoLOGY L.Q. 597 (1973); Note, 


\title{
Subsequent Legislative and Administrative Developments
}

\section{Legislative developments since the passage of NEPA have not}

\begin{abstract}
A Fight Between Friends: EPA v. The National Environmental Policy Act of 1969, 69 GEO. L.J. 913 (1974).

There was an attempt in 1973 by some members of Congress to resolve the doubts as to whether NEPA applies to the EPA by inserting clarifying language into another piece of legislation, the Agriculture-Environmental and Consumer Protection Appropriation Act for 1974, Pub. L. 93-135, 87 Stat. 468 (Oct. 24, 1973). This act appropriated $\$ 5,000,000$

to provide for the preparation of Environmental Impact Statements as required by section 102(2)(C) of the National Environmental Policy Act on all proposed actions by the Environmental Protection Agency, except where prohibited by law. . . Id. at 482 (empliasis added).
\end{abstract}

Although the language of this provision appears to be unequivocal in its requirement of an impact statement for most actions proposed by the EPA, its legislative history casts some doubt on its actual significance. When the conference version of the bill was considered in the House of Representatives, Congressman Dingell, who had introduced the original House version of NEPA, took the position that this provision was merely a restatement of law as it existed at that time. He made it clear that under his view of the then-present law the EPA was permitted an exemption from the mandate of NEPA only in two narrow situations-where there existed a specific statutory exemption of the agency from NEPA and where the best interests of NEPA would be served by dispensing with the formal requirements of section 102(2)(C) of NEPA. See 119 Cong. Rec. H8307 (daily ed. Sept. 25, 1973) (remarks of Mr. Dingell). Representative Dingell relied in part upou an opinion of the General Accounting Office, the Comptroller General's opinion of June 6, 1973 (B-170,186), which had been prepared in response to a request by the Congressman for an opinion on the basic issue. Concluding that "the plaiu words of the applicable statute require the conclusion that the EPA is subject" to the impact statement requirement, this opinion took the position that the EPA, as a federal agency, must comply with NEPA along with all other federal agencies. Id. At the same time, however, the GAO report lad wamed that "this complicated issue is currently the subject of hitigation and the final determination of EPA's responsibilities under NEPA is in the hands of the judiciary." Id. See also 4 BNA ENVIRONMENT REP. 892 (1973).

In the Senate, the conferees likewise expressed the view that the appropriation provision was not intended to change existing law. 119 CoNG. REC. S18,977-78 (daily ed. Oct. 10,1973) (remarks of Senators McGee and Fong). This conclusion was predicated on the observation that neither louse permits legislation in an appropriation bill. See id. at S18,977 (daily ed. Oct. 10, 1973) (remarks of Senator Fong). See also SENate Comm. on Rules and Administration, Standing Rules of the United States Senate and Provisions of the Legislative Reorganization Acts of 1946 aNd 1970 Relating to Operation of the Senate, Rule XVI(2) (1972). Accordingly, the Senate view of the provision in the appropriation act which requires the EPA to file inpact statements on all proposed actions except where prohibited by law neither "add[s] to, nor subtract[s] from, existing law governing the Environmental Protection Agency." 119 CoNG. Rec. S18,977 (daily ed. Oct. 10, 1973) (remarks of Senator Fong). However, the two houses appear to liave been completely at odds as to the more important question of what the existing law is. The view expressed in the Senate was that NEPA does not apply to the regulatory activities of environmental agencies such as the EPA. Id. at S18,977-78 (daily ed. Oct. 10, 1973) (remarks of Senator Fong). Therefore, if the original purpose of the provision making this $\$ 5,000,000$ appropriation to the EPA was to clarify the issue as to whether the EPA is required to comply with NEPA, it apparently has failed. 
resolved the question of NEPA's applicability to the EPA. Section 511(c) of the 1972 amendments to the Federal Water Pollution Control Act (FWPCA) ${ }^{26}$ state that section 102(2)(C) of NEPA is not applicable to EPA activities under that Act except where grants are made for the construction of publicly owned waste treatment works and where the agency issues permits for projects constituting new sources of water pollution. The EPA, which has maintained that its regulatory activities are completely exempt from NEPA, has argued that this provision is an affirmation of an allegedly preexisting congressional intent regarding the mapplicability of NEPA to the EPA. ${ }^{27}$ On the other liand, opponents of this view have taken the position that the very existence of section 511(c) in the 1972 amendments illustrates that Congress recognized the need to create a specific statutory exemption, because Congress, in originally enacting NEPA, in no way intended to exempt the predecessors of the EPA froin NEPA's environmental impact statement requirements and thus not the EPA itself. ${ }^{28}$ These contrary interpretations of the section 511(c) exemption were also reflected in the congressional debate which preceded section 511(c)'s adoption. ${ }^{29}$ But, even assuming that the debate predominantly favored either view of the issue, the opinion of the later Congress which enacted section 511(c) would be at best a "hazardous basis" for inferring the intent of an earlier Congress in enacting NEPA. ${ }^{30}$

Title II of NEPA created the Council of Environmental Quality (CEQ) in the Executive Office of the President. ${ }^{31}$ The CEQ's function is primarily advisory and imcludes the duty to advise the President on matters of environmental policy, to assist in the preparation of the annual Environmental Quality Report, and to review and appraise the environmental aspects of the various programs of the federal government. ${ }^{32}$ By executive order the CEQ is authorized to issue advisory

26. 33 U.S.C. $\$ 1371$ (c) (Supp. II 1972).

27. See, e.g., Anaconda Co. v. Ruckelshaus, 352 F. Supp. 697, 713 (D. Colo. 1972), rev'd on other grounds, 482 F.2d 1301 (10th Cir. 1973).

28. See Brief for Long Island Lighting Co. as Amicus Curiae at 3, Essex Chem. Corp. v. Ruckelshaus, 486 F.2d 427 (D.C. Cir. 1973). The Brief makes the further argument that the fact that Congress found it necessary to create an express 'exemption from NEPA indicates that "Congress never intended to allow backdoor exemptions to NEPA by implication." Id.

29. 118 Cong. REc. $\$ 16,877-90$ (daily ed. Oct. 4, 1972); id. at H9118-27. See also ANDERSON 115-16.

30. United States v. Southwestern Cable Co., 392 U.S. 157, 170 (1968); Waterman S.S. Corp. v. United States, 381 U.S. 252, 269 (1965); Portland Cement Ass'n v. Ruckelshaus, 486 F.2d 375, 382 (D.C. Cir. 1973).

31. 42 U.S.C. $\$ 4342$ (1970).

32. Id. $\S 4344$. 
guidelines to federal agencies governing the preparation of environmental impact statements. ${ }^{33}$ Based on its own interpretation of NEPA's legislative history, ${ }^{34}$ the CEQ imitially took the position in its first set of guidelines that the EPA's regulatory activities are exempt from section 102(2)(C) of NEPA. ${ }^{35}$ However, in its 1973 revision of these guidelines, the $\mathrm{CEQ}$, without expressly reversing its position, retracted the broad claim that the EPA was in no way subject to the requirements of NEPA. ${ }^{36}$ The EPA strongly resisted the removal of its specific exemption from the CEQ Guidelines and has steadfastly maintained its position that Congress did not intend its regulatory activities to be subject to the mandate of NEPA. ${ }^{37}$ At the same time, the EPA has taken some action to coinply with NEPA, without conceding that it is actually subject to NEPA's prescriptions. In 1973 the EPA announced that it would publish "full explanations" when it proposes "major standards, regulations, and guidelines . . . which either prescribe national standards of environmental quality, or require national emission, effluent, or performance standards or limitations." 38

33. Exec. Order No. 11,514, 3 C.F.R. 285 (1973).

34. The CEQ did not specify the portions of NEPA's legislative history upon which it based its interpretation. See 1973 DUKE L.J. 347, 349, in 1972 Developments.

35. CEQ GUDELINES $\$ 5$ (d), 36 Fed. Reg. 7724, 7725 (1971).

36. CEQ GudDelines, 38 Fed. Reg. 20,550 (1973). See Section-by-section Comment and Explanation of Major Proposed Revisions, 38 Fed. Reg. 10,865 (1973), where the CEQ relied upon section 511(c) of the 1972 amendments to the FWPCA as its reason for making the deletion. See text accompanying notes 26-30 supra. But the CEQ did not atteinpt to explain why this specific statutory exemption necessitated a full retraction. In any event, the CEQ lias in effect shifted the entire responsibility for justifying any exemption for the EPA from NEPA to the EPA itself by stating that the issue will be addressed in the EPA's revised "NEPA procedures." 38 Fed. Reg. 10,865 (1973). Every federal agency, including the EPA, is required to prepare, publish, and periodically revise such "procedures" to identify those agency actions which require impact statements and to outline the agency's internal procedures for their preparation. CEQ GUIDELINES $\$ 3$ (a), 38 Fed. Reg. 20,550 (1973).

37. See 4 BNA ENVIRonment REP. 440 (1973). In any event, the CEQ's interpretation of NEPA has no legal significance. Cf. Portland Ceinent Ass'n v. Ruckelshaus, 486 F.2d 375, 382-83 n.3 (D.C. Cir. 1973) (an advisory agency is in no better position than a court of appeals to interpret legislative history); Hiram Clarke Civic Club, Inc. v. Lynn, 476 F.2d 421, 424 (5th Cir. 1973) (CEQ does not have autlority to prescribe regulations governing compliance with NEPA). But cf. 1972 Duke I.J. 667, 677 (argument that the CEQ Guidelines liave the force of law). Thus, the CEQ's action in revising the Guidelines inay amount to nothing more than a decision to leave the determination of the legal obligations of the EPA under NEPA up to the judiciary.

38. Major Standards, Regulations, and Guidelines, 38 Fed. Reg. 15,653 (1973). The procedure went into effect on December 31, 1973. This form of intermediate compliance was suggested by an EPA task force report which studies the anticipated burden of full compliance with NEPA by the EPA. U.S. ENVIRONMENTAL ProteCtion Agency, Application of the National Environmental policy Act to EPA's ENVIRONMENTAL REGULATORY ACTIVITIES 81-82 (1973). 
The EPA set forth two considerations underlying the decision to establish these procedures: (1) a belief that "the public should be fully apprised of the environmental effects of the Agency's major standardsetting actions;"39 and (2) a belief that "the public should be provided with detailed background information to assist it in commenting on the merits of a proposed action." 40 While it is true that by informing the public, these "explanations" fulfill one of the purposes of an impact statement, ${ }^{41}$ they have nonetheless been criticized as "disappointing half measure[s]"42 because these environmental "explanations" fall short of the protections offered by full impact statements in several important respects: (1) there is no requirement that the "explanations" be made available to the President and the CEQ, nor that they be circulated among other agencies; ${ }^{43}$ (2) there is no provision for the "explanations" to accompany the proposal through the existing agency review processes; ${ }^{44}$ (3) there is no opportunity for review of the adequacy of the "explanations" in the courts; 45 and (4) there is no assurance that the five factors which must be considered in the preparation of the detailed impact statement be taken into account im preparation of the "explanations." 46

39. 38 Fed. Reg. 15,653 (1973).

40. $I d$.

41. See 42 U.S.C. $\$ 4332(2)(C)(1970)$.

42. See Comment, supra note 22 , at 10,139 .

43. Compare with 42 U.S.C. \$ $4332(2)(C)$ (1970).

44. Compare with id.

45. While neither NEPA nor its legislative history mentions judicial review, the courts "have been vigorous in reviewing agency compliance with NEPA." ANDERsoN 16. For a thorough discussion of judicial review under NEPA, see Note, Judicial Review, Delegation and Public Hearings Under NEPA, 1974 DUKE L.J. 423, in 1973 Developments.

46. Compare with 42 U.S.C. $\$ 4332$ (1970), the five requirements of which are set forth in note 1 supra.

The EPA directive does prescribe the content of an "explanation" as follows:

(a) Information available to the Agency delineating the major environmental effects of the proposed action;

(b) A discussion of pertineut non-environmental factors affecting the decision including, where relevant under the applicable statute, legal, technical, social, and economic factors; and

(c) An explanation of viable options available to the Agency, and the rationale for the option selected, in sufficient detail to apprise a reader, not an expert in the subject matter involved, of the issues. 38 Fed. Reg. 15,653 (1973).

While these elements reflect some of the considerations which must be taken into account in the preparation of an impact statement, they are clearly not as comprehensive as those specified for full impact statements. Furthermore, these elements of the EPA "explanations" simply do not rise to the level of an enforceable mandate as in the case of the action-forcing provisions of NEPA. A further criticisin of the adoption of these new EPA "regulations" was made by Congressman Dingell during the congressional debate over the Agriculture-Environmental and Consumer Protection Act of 1974. 


\section{DIVERgENT JUdiclal APPROACHES}

\section{Strict Procedural Compliance}

The first case actually to consider the applicability of NEPA to the EPA was Anaconda Co. v. Ruckelshaus, ${ }^{47}$ which involved regula-

He suggested that the Act was in part an attempt "to circumvent NEPA's requirements and ... to gain congressional endorsement for this approach" through passage of the Senate version of that Act which would have appropriated funds for such environmental "explanations." 119 CoNG. REC. H8306 (daily ed. Sept. 25, 1973) (remarks of Mr. Dingell); see note 25 supra. Congressinan Dingell also raised the objection that the new EPA "regulations" were adopted "without benefit of public comment thereon as required by the rulemaking provisions of the Administrative Procedure Act (5 U.S.C. § 553)." 119 CoNG. Rec. H8306 (daily ed. Sept. 25, 1973) (remarks of Mr. Dingell).

47. 352 F. Supp. 697 (D. Colo. 1972), rev'd on other grounds, 482 F.2d 1301 (10th Cir. 1973). In a previous case, Getty Oil Co. v. Ruckelshaus, the Third Circuit had touched on the issue, but only by way of dictum. 467 F.2d 349 (3d Cir. 1972), cert. denied, 409 U.S. 1125 (1973). Getty Oil involved the application by a Delaware oil refinery operator for prelininary and permanent imjunctions and a temporary restraining order staying the effect of a compliance order issued by the Administrator pursuant to section 113 of the Clean Air Act, 42 U.S.C. $\$ 1857 \mathrm{c}-8$ (1970), requiring the company to comply with a Delaware state air pollution regulation that had been approved by the EPA. Getty Oil argued that by failing to file an impact statement, the EPA's compliance order was ultra vires. In affirming the district court's denial of Getty Oil's application, the Third Circuit held that section 307 of the Clean Air Act, 42 U.S.C. $\$ 1857 \mathrm{~h}-5(1970)$, required the plaintiff to raise any NEPA objection at the time the state implementation plan was under consideration, not in an enforcement proceeding, 467 F.2d at 359. See Colnment, supra note 22, at 10,140; 1973 DukE L.J. 347, $354 \mathrm{n.4}$, in 1972 Developments. Because of this procedural deficiency in the plaintiff's presentation of his clain, the court did not even reach the merits of Getty Oil's contention that the EPA's failure to file an inpact statement rendered the action of the EPA in issuing the compliance order ultra vires. But the court did note that it found the authority for Getty's contention unpersuasive. 467 F.2d at 359 n.17.

The authority relied upon by Getty Oil was Kalur v. Resor, 335 F. Supp. 1 (D.D.C. 1971) and Environinental Defense Fund v. Hardin, 325 F. Supp. 1401 (D.D.C. 1971). Kalur held that the Army Corps of Engineers was required to prepare an impact statement before issuing a permit to dump refuse into a navigable waterway in accordance with the Rivers and Harbors Act of 1899, 33 U.S.C. \& 407 (1970). The 1972 Amendments to the Federal Water Pollution Control Act transferred this refuse permit responsibility to the EPA and exempted the EPA from the NEPA impact statement requirement for that function. See note 26 supra and accompanying text. As a result of this legisiation, Kalur was dismissed as moot several months after the Getty Oil case and therefore no longer retains precedential value. See Portland Cement Ass'n v. Ruckelshaus, 486 F.2d 375, 385 n.41 (D.C. Cir. 1973). It is likely that the FWPCA was amended because of the holding in Kalur. See Anaconda Co. v. Ruckelshaus, 352 F. Supp. 697, 711 n.7 (D. Colo. 1972), rev'd on other grounds, 482 F.2d 1301 (10th Cir. 1973).

In Environmental Defense Fund v. Hardin, the District Court for the District of Columbia denied a motion to enjoin the Secretary of Agriculture from undertaking a program to control the fire ant by chemical means. In so doing the court noted that the use of substances registered under FIFRA does not exempt the program from the requirements of NEPA nor does withdrawal of the registration under FIFRA deprive the court of jurisdiction under NEPA. 325 F. Supp. at 1407. 
tory action taken by the EPA pursuant to section 110 of the Clean Air Act. 4 That section establishes procedures for the adoption by the EPA of plans designed by each state to provide for the implementation, maintenance, and enforcement of primary and secondary national ambient air quality standards ${ }^{49}$ and authorizes the EPA Administrator himself to prepare and implement such a plan if the state plan is inadequate or if the state refuses to submit a plan..$^{50}$ In Anaconda, the operator of a copper smelter in Montana challenged the promulgation by the EPA Administrator of a proposed plan to control emission of sulphur oxides, a common by-product of copper smelting, following the failure of the state to provide a control strategy for these pollutants in the plan it had submitted in an effort to comply with the requirements of section $110 .{ }^{51}$ The plaintiff company sought to enjoin implementation of the EPA plan on the ground that the EPA had failed to prepare an environmental impact statement prior to adopting the plan. ${ }^{52}$ The EPA contended first that it was not subject to this

This case probably was not regarded as persuasive authority for the proposition that the EPA is required to comply with NEPA for several reasons: (1) even though the Department of Agriculture is a quasi-environmental agency which administered FIFRA prior to the creation of the EPA, it does not necessarily follow that the EPA is subject to the same determinations that were made with respect to its predecessor. See note 25 supra and accompanying text. The primary function of the Department of Agriculture is not consideration of environinental factors, but promotion of agriculture; and (2) the case did not actually consider whether the FIFRA procedures for the registration or cancellation of a chemical insecticide in themselves satisfy NEPA. Rather, the case merely held that the entire fire ant control program, of which the FIFRA proceeding was only a part, was a major federal action requiring a NEPA statement. Id.

48. 42 U.S.C. $\$ 1857 \mathrm{c}-5$ (1970).

49. Id. The national ambient air quality standards are established by the Administrator for each pollutant in accordance with section 109 of the Clean Air Act. Id. A primary standard is defined in that section as an ambient air quality standard "the attainment and maintenance of which ... [is] requisite to protect the public health." Id. $-4(\mathrm{~b})(1)$. A secondary standard is one uecessary to protect "the public welfare from any known or anticipated adverse effects associated with the presence of such air pollutant in the ambient air." Id. -4 (b)(2). Under the Act each state is required to submit an implementation plan to the Administrator of the EPA for his approval. Id. -5 .

50. Id. $-5(\mathrm{c})$. Under the terms of section 110, id. $-5(\mathrm{a})(2)$, the Administrator may only approve a state plan if it satisfies the requirements of that section and is based on the national ambient air quality criteria established under the Act. See 1973 DURE. L.J. $347 \mathrm{nn} .4,6$, in 1972 Developments.

51. 352 F. Supp. at 700 .

52. Thus, Anaconda involved the unusual situation in which the protections of the procedural requirements of NEPA were being invoked not by the traditional environmentally-minded plaintiff, but by a component of industry. $C f$. ANDERSON 121-22. Actually, it should come as no real surprise that the industrial sector has sought refuge within the procedural requirements of NEPA. As Anaconda illustrates, if the EPA 
requirement of NEPA, because NEPA does not apply to environmental agencies. ${ }^{53}$ The EPA's principal argument in favor of this proposition was that the exemption from NEPA created for the EPA by the 1972 amendments to the FWPCA ${ }^{54}$ was applicable not only to the FWPCA, but also to other federal environmental legislation, imcluding the Clean Air Act. ${ }^{55}$ Denominating this argument a "masterful non sequitur," the Anaconda court rejected it by observing that the plain wording of the FWPCA amendment exempts the EPA from NEPA only as to action taken under the FWPCA. ${ }^{56}$ The EPA further contended that, presumably even if NEPA were held to apply generally to the EPA, the Clean Air Act permits consideration of nothing other than air purity in the establishinent of air quality standards. ${ }^{57}$ Under this argument, the limited scope of discretion allowed the EPA when it undertakes to set standards under the Clean Air Act precludes consideration of alternatives or a weighing of costs and benefits which is required by NEPA. The District Court for the District of Colorado rejected this argument as well, refusing to accept the notion that Congress desired the EPA to ignore the cost of implementation measures

sets a standard for control of one pollutant without being forced to consider the effect that full compliance by industry will have on other forms of pollution, then industry may encounter excessive costs, or even find itself unable to coinply at all, when faced with a combination of regulations:

[M]t is starkly clear that when an environmental agency says that its duty is to protect one part of the environment even thougl that protection causes great harm to another part of the environment, Congress was possessed of great wisdom when it said that all governmental agencies must file NEPA statements where there is major federal action. We thought that environmental agencies would be the ones which would be the most concerned with the broad picture of environmental impact and harm, but our naivete is demonstrated by the record in this case. Anaconda Co. v. Ruckelshaus, $352 \mathrm{~F}$. Supp. 697, 710 (D. Colo. 1972), rev'd on other grounds, 482 F.2d $130 \mathrm{i}$ (10th Cir. 1973) (emphasis in original).

53. 352 F. Supp. at 710 . In partial support of this contention, the EPA relied upon dicta in Getty Oil Co. v. Ruckelshaus, 467 F.2d 349 (3d Cir. 1972), cert. denied, 409 U.S. 1125 (1973). See note 47 supra. The Anaconda court rejected this argument on two grounds. First, as noted above, the Getty Oil court had not speeifically addressed this question. Furthermore, the proposed stationary standards contested in $A n$ aconda may have forced Anaconda to spend millions of dollars over and above the amounts necessary to meet the EPA's national ambient air quahity standards and may have created other significant problems of air and water pollution and of solid waste disposal. 352 F. Supp. at 701-02. Thus the Anaconda court found itself, more clearly than the court in Getty Oil, confronted by a proposed rule which could do great harm to other aspects of the environment, the econoiny, and the public welfare. $352 \mathrm{~F}$. Supp. at 710 .

54. See notes 26-30 supra and accompanying text.

55. Anaconda Co. v. Ruckelshaus, 352 F. Supp. 697, 713 (D. Colo. 1972), rev'd on other grounds, 482 F.2d 1301 (10th Cir. 1973).

56. Id.

57. Id. at 704-05, 710. 
taken pursuant to the Clean Air Act.58 Rather, the court examined the language of NEPA itself and the cases which have construed it and concluded that, taken together, these factors clearly imply that NEPA applies to all federal agencies. ${ }^{59}$ The court then explicitly reduced the question to a simple syllogism:

Major premise: All federal agencies must file a NEPA statement.

Minor premise: EPA is a federal agency.

Conclusion: EPA must file a NEPA statement. ${ }^{60}$

Although this reasoning is logically appealing, another count later rejected the argument as "more simplistic than simple," the weakness of the "myopic" approach taken by the Anaconda district court was its reliance "on the non-obvious premise that EPA is a 'federal agency' within the meaning of NEPA."62 As has been noted above, the EPA was clearly not a "federal agency" at the time of the enactment of NEPA because it was not then im existence. ${ }^{63}$ Whatever apparent validity the questionable reasoning of the district court im Anaconda may have, its precedential impact was substantially impaired by the reversal of the case on other grounds on appeal. ${ }^{64}$

58. Id. at 705 .

59. $352 \mathrm{~F}$. Supp. at 710-14. The court relied upon numerous cases primarily from the Tenth Circuit which support its conclusion that section 102(2)(C) of NEPA did not carve out an exception for any federal agency. E.g., Davis v. Morton, 469 F.2d 593 (10th Cir. 1972); National Helium Corp. v. Morton, 455 F.2d 650 (10th Cir. 1971); Upper Pecos Ass'n v. Stans, 452 F.2d 1233 (10th Cir. 1971), vacated, 409 U.S. 1021 (1974); Calvert Cliffs' Coordinating Comm., Inc. v. AEC, 449 F.2d 1109 (D.C. Cir. 1971); Kalur v. Resor, 335 F. Supp. 1 (D.D.C. 1971).

60. 352 F. Supp. at 713 .

61. Portland Cement Ass'n v. Ruckelshaus, 486 F.2d 375, 379 (D.C. Cir. 1973).

62. Id. at 385 n.41.

63. See notes 23,24 supra and accoinpanying text.

64. The Tenth Circuit reversed the district court's granting of the injunctive relief on two related jurisdictional grounds. First, the court lield that appeal to a district court by an aggrieved party for a stay of an implementation plan proposed by the EPA was inappropriate, since section $307(b)(1)$ of the Clean Air Act, 42 U.S.C. $§ 18571$ 5(6)(1) (1970), specifically designates the Court of Appeals as the exclusive forum for review of such a plan. Anaconda Co. v. Ruckelsliaus, 482 F.2d 1301, 1304-05 (10th Cir. 1973). The court found another reason for denying relief in the fact that, although there was only one party to whom the regulations could possibly be applied, 352 F. Supp. at 700, they were merely "proposed" in form rather than formalized and final. 482 F.2d at 1305 . Consequently, the Tenth Circuit did not reach the merits of the contention of the Anaconda Company that the EPA must comply with NEPA. Id.

It slould be noted, however, that there is strong dictum indicating that the Tenth Circuit in Anaconda disagreed with the district court's holding that the EPA was required to file an impact statement under NEPA: "[T]he EPA's sole mission is to inprove the quality of the liuman environment. To compel the filing of impact statements could only serve to frustrate the accomplishment of the Act's objectives." 


\section{Complete Exemption from Compliance}

A number of 1973 cases considered the argument that the EPA is required to comply with section 102(2)(C) of NEPA. The Fourth Circuit case of Appalachian Power Co. v. EPA $A^{05}$ involved a challenge similar to that in Anaconda of the adoption by the EPA of three state plans for implementation of federal ambient air quality standards under the Clean Air Act. ${ }^{B 6}$ In a brief paragraph the court flatly held that NEPA is "inapplicable to the action of the Administrator in seeking, through the approval of state implementation plans, to improve "the quality of the human environment." "or The court attempted, albeit with rather dubious success, to justify its unequivocal holding by observing that "the Clean Air Act itself contains sufficient provisions for the achievement of those goals sought to be attained by NEPA."

Id. at 1305-06. The court went on to say, relying on the Portland Cement case, see notes 3-8 supra and accompanying text, that the legislative history "clearly" establishes that such a holding was not conteinplated by Congress, id. at 1306, although the court in Portland Cement actually found the legislative history to be inconclusive on the issue. 486 F.2d at 383.

The Tenth Circuit did qualify its dictum by stating that the EPA must consider alternative factors in arriving at the decision to approve a state implementation plan:

This is not to say that the EPA is exempt from weighing and considering other environmental effects of its order. Being engaged in the environmental improveinent effort, it inust weigh these and other factors such as economics. It should, of course, inquire as to whether, for example, water pollution will result froin its instant air cleaning program. No doubt it will fully weigh and consider these factors. We cannot assnine that the administrative hearing will be a mere formality, that it will turn out to be a rubber stamp operation. If it is deficient, however, the reviewing court can soon remedy the condition. 482 F.2d at 1306.

It is not clear froin the wording of the Tenth Circuit's statement whether it regards the EPA's responsibility under the Clean Air Act as one which requires full functional compliance with the basic mandate of NEPA or whether the standard for consideration of alternatives can be satisfied by something less. See notes 8,12 stipra and accompanying text.

65. 477 F.2d 495 (4th Cir. 1973).

66. The petitioners in Appalachian Power were operators of power plants in Virginia and West Virginia and a steel manufacturer in Maryland, who were seeking remand to the EPA of its approval of the states' plans for meeting the national ambient air qnality standards with instructions that the Administrator provide an evidentiary hearing and file an impact statement. Id. at 499-500. The conrt refused to consider a motion for remand until the Adıninistrator had certified a full administrative record for consideration by the reviewing court. Id. at 507. In so doing, the court held that if it found, upon receiving and reviewing the full record, that the hearings which had been conducted by each state prior to submission of its plan to the Adininistrator were adequate and that the Administrator had reviewed those state hearings, then the Administrator would not be required to hold further hearings prior to approval of the state plan. Id. at 504. Accordingly, the motions were denied without prejudice to right to renew.

67. Id. at 508 .

68. Id., quoting Getty Oil Co. v. Ruckelshaus, 467 F.2d 349, 359 (3d Cir. 1972), cert. denied, 409 U.S. 1125 (1973). The Third Circuit's statement in Getty Oil was 


\section{In Duquesne Light Co. v. EPA, ${ }^{69}$ the Third Circuit, relying primarily}

predicated on three sections of the Clean Air Act: "[T]he Administrator is given the responsibility of making policy reviews under 42 U.S.C. $\$ 1857$ j-7, annual comprehensive economic cost studies under 42 U.S.C. $\$ 1857 \mathrm{j}-1$, and periodic reports to Congress under section 1857j-2." 467 F.2d at 359. The last two of these provisions, the annual comprehensive cost studies and the periodic reports to Congress, have, however, been regarded by another court as not affording as great a degree of protection of environmental values as NEPA because they are post decision reporting requirements and do not "offer the same timely and substantive impact on decision making as would comments on possible adverse environmental impact during a rule-making proceeding." Portland Cement Ass'n v. Ruckelshaus, 486 F.2d 375, 384 n.40 (D.C. Cir. 1973).

Section 309 of the Clean Air Act, 42 U.S.C. $\$ 1857 \mathrm{~h}-7$ (1970), the provision of the Act governing policy reviews by the Administrator and the other provision of the Clean Air Act rehed upon by the Getty Oil court in its conciusion that the goals of NEPA are sufficiently provided for in the Clean Air Act, states that:

(a) The Administrator shall review and comment in writing on the environmental impact of any matter relating to duties and responsibilities granted pursuant to this chapter or other provisions of the authority of the Administrator, contained in any (1) legislation proposed by any Federal department or agency, (2) newly authorized Federal projects for construction and any major Federal agency action (other than a project for construction) to which section 4332(a)(C) of this title applies, and (3) proposed regulations published by any department or agency of the Federal Government. Such written coinment shall be made public at the conclusion of any such review.

(b) In the event the Administrator determines that any such legislation, action, or regulation is unsatisfactory from the standpoint of public health or welfare or environmental quality, he shall publish his determination and the matter shall be referred to the Council on Environmental Quality. 42 U.S.C. $\S 1857 \mathrm{~h}-7$ (1970).

The District of Columbia Circuit in Portland Cement took the position that this section offers little guidance to the resolution of the basic issue of whether NEPA's requirement of an inpact statement extends to actions by the EPA:

That section merely requires the Administrator to review and comment in writing on the impact on the environment of projects of another federal agency "[which contains (sic)] any matter relat[ed] to duties and responsibilities granted [to the Administrator] pursuant to this chapter." The contention that this section implies the Administrator must file a draft impact statement can only be resolved in the framework of the legislative history which we have already reviewed. Portland Cement Ass'n v. Ruckelshaus, 486 F.2d 375, 383 n.35 (D.C. Cir. 1973).

Thus the straightforwardness of the Appalachian Power court's application of NEPA to the EPA seems to have exceeded to a considerable degree the soundness of its rationale.

69. 481 F.2d 1 (3d Cir. 1973). Duquesne, like Anaconda and Appalachian Power, was a case arising under section 110 of the Clean Air Act. In January 1972, the commonwealth of Pennsylvania submitted an inplementation plan for control of sulphur oxides, which was approved in part and disapproved in part by the Administrator in May 1972. 481 F.2d at 5. The Administrator then incorporated restrictions on power plant emissions in adopting the state implementation plan. The petitioners, two power companies, then challenged these restrictions and sought to have the matter remanded to the EPA for reconsideration and to have the EPA prepare an impact statement prior to reapproving the plan. In addition to its determination that the EPA is not required to file an impact statenent, the Third Circuit held that the matter should be remanded to the EPA to conduct a limited legislative hearing or, in the alteruative, to refrain from enforcing the plan against the two petitioning companies until they had had an opportunity to exhaust their state administrative and judicial remedies. $I d$. at 10 . 
upon the Appalachian Power decision, held that it would be "redundant" to require the EPA to file environmental impact statements because its only function is to protect the environment. ${ }^{70}$ In Buckeye

70. Id. at 9, citing International Harvester Co. v. EPA, 478 F.2d 615, 650 n.130 (D.C. Cir. 1973); Appalachian Power Co. v. EPA, 477 F.2d 495, 508 (4th Cir. 1973); Getty Oil Co. v. Ruckelshaus, 467 F.2d 349, 359 (3d Cir. 1972); Getty Oil Co. v. Ruckelshaus, 342 F. Supp. 1006, 1020-22 (D. Del. 1972). Neither Getty Oil, see note 47 supra, nor International Harvester actually reached the merits of the issue. International Harvester involved a challenge to the EPA's refusal to suspend for one year its 1975 automobile emission standards. The EPA's failure to comply with $\$ 102(2)(C)$ of NEPA was merely one of several grounds relied upon by International Harvester and other vehicle manufacturers to attack the EPA decision. The Court of Appeals for the District of Columbia remanded the matter to the EPA for further proceedings, on the grounds that the petitioners had established by a preponderance of the evidence in the record that the technology was not available, within the meaning of the Clean Air Act, to achieve the standard, and that the Administrator had failed to meet his resulting burden of proving that the standards could be met. 478 F.2d at 648 . The court further observed that the disposition on remand would require a "public interest determination," which would satisfy the objectives of NEPA. Id. at 650 n.130. The court defined the purpose of NEPA to be "to assure presentation to Congress and the public of the environmental impact of executive action," which purpose necessarily would be served by making a public interest determination of the petitioners' request for a one-year suspension. Id. The EPA had a very narrowly defined statutory role in this case to grant or to deny the one-year suspension-all alternatives would be exhausted in making the either-or decisiou. The court did not, therefore, consider the merits of a broader exemption. However, the court did touch on this issue in a frequently cited footnote:

Although we do not reach the question whether EPA is automatically and completely exempt from NEPA, wo see little need in requiring a NEPA statement from an agency whose raison d'être is the protection of the environment and whose decision on suspension is necessarily infused with the environmental considerations so pertinent to Congress in designing the statutory framework. To require a "statement" in addition to a decision setting forth the same considerations, would be a legalism carried to the extreme. Id.

This bit of dictum has been seized upon by various courts for various purposes. For example, in Duquesne Light Co. v. EPA, 481 F.2d 1, 9 (3d Cir. 1973), discussed in note 69 supra and accompanying text, the Third Circuit focused on the language "we see little need in requiring a NEPA statement from an agency whose raison d'être is the protection of the environment" to support a rather broad view of the EPA's exemption. On the other hand, in Environmental Defense Fund, Inc. v. EPA, 489 F.2d 1247, 1256 n.58 (D.C. Cir. 1973), discussed in notes 9-13 supra and accompanying text and in notes 89-96 infra and accompanying tcxt, the District of Columbia Circuit relied upon the phrase-c"To require a 'statement,' in addition to a decision setting forth the same considerations would be a legalism carried to the extreme"-to support a very narrow exception predicated upon the EPA's issuance of a "functional equivaleut" to a NEPA statenent. Environmental Defense Fund did not reach the question of whether the EPA is entitled to a broader exemption for all regulatory activities. Id. at 1247.

One commentator has analyzed the International Harvester footnote as follows:

The language of the footnote inakes it clear that the court is ruling solely on the question where there is no environmental issue which the Agency has discretion to cousider; Congress' decision has foreclosed any discretion within the Agency as to standards and has left it solely with the task of determining as a technical matter whether the standards can be met in 1975 or 1976 . De- 
Power, Inc. v. $E P A,{ }^{71}$ the plaintiff power companies also challenged the EPA's approval of state plans for implementation of ambient air quality standards on the grounds that the agency had not filed an environmental impact statement prior to its determination. ${ }^{72}$ The Sixth Circuit held that the EPA is not required to comply with NEPA in making such decisions, reasoning that to impose such a requirement "would mean that an agency whose sole purpose is improvement of the environment, would have to file an Environmental Impact Statement with itself." T3 The rationale for the decision was predicated on the simple view that since the EPA's mission is to make decisions affecting the environment, it is not necessary to impose upon it a procedural requirement which is designed to ensure agency consideration of the environmental impact of its decisions. Hence, these three 1973 cases-Appalachian Power, Duquesne, and Buckeye Power-representing the common view of the Third, Fourth, and Sixth Circuits, suggest a broad or blanket exemption of the EPA from the requirements of NEPA. ${ }^{74}$ However, none of these decisions rigorously analyzed the problem to consider whether the purpose of NEPA would be served by exempting the EPA from its mandate nor do any of these opinions

spite the court's loose statement about statements from an agency "whose rai-
son d'etre is the protection of the environment," the final sentence-which
shows that the court believed the Administrator's ruling on the standards sus-
pension fulfilled the role of a NEPA statement-demonstrates that no general
conclusion as to NEPA's application to EPA or to Clean Air Act matters
as a whole can be drawn from the footnote. Comment, Litigation Under the
Clean Air Act, 3 ENVRONMENrAL L. REP. 10,007, 10,017 (1973).

71. 481 F.2d 162 (6th Cir. 1973).

72. Id. at 164-65. The petitioners were Ohio and Kentucky public utility power companies. The grounds for complaint relied upon by the petitioners were (1) the Administrator did not permit imterested parties to participate $\mathrm{m}$ the proceedings as required by section 4 of the Administrative Procedure Act (APA), 5 U.S.C. $\$ 553$ (1967); (2) the plans were approved without regard to any impossibility of complance by the petitioners; and (3) the Administrator failed to file an environmental impact statement. Id. at 165 . The court held (1) that it was a violation of the APA to refuse to permit imterested parties to participate in the proceedings, (2) that it was not necessary to conduct full hearings on the impossibility claims of the individual petitioners since such claims could be raised as a defense in future enforcement proceedings, and (3) that the Administrator was not required to file a NEPA statement. Id.

73. Id. at 174 .

Buckeye Power claimed to be in accord with the Third (Getty Oil Co.), Fourth (Appalachian Power), and D.C. (International Harvester) Circuits in holding that the EPA is exempt from NEPA. 481 F.2d at 174. As one commentator has observed

[t]his was, of course, a misstatement with regard to the D.C. Circuit, which issued no "holding" on the issue [see note 53 supra], and was somewhat misleading as to the breadth of the holding of the other two courts. Comment, supra note 22 , at 10,141 .

74. International Harvester Co. v. Ruckelshaus, 478 F.2d 615 (D.C. Cir. 1973), is not included in this line of cases, even though others rely upon it, because of the various interpretations given to its holding. See note 70 supra. 
discuss the limits of such an exemption.

\section{The Functional Equivalence Doctrine}

In contrast, the Court of Appeals for the District of Columbia Circuit in Portland Cement Association v. Ruckelshaus ${ }^{75}$ and Environmental Defense Fund, Inc. v. EPA, ${ }^{76}$ attempted to approach the central issue with the policies underlying NEPA firmly in mind. While these cases did not find it necessary to go beyond the recognition of a narrow exception in exempting from NEPA the particular regulatory activities of the EPA which had been called into question, ${ }^{77}$ the court did search for a solution which would "strike a workable balance between some of the advantages and disadvantages of NEPA."78 Through a careful analysis of the language of section 111 of the Clean Air Act, the Portland Cement court ${ }^{79}$ reached the conclusion that section 111 of the Clean Air Act requires the functional equivalent of a NEPA statement. Section 111 requires the EPA to set "standards of performance" for new or modified sources of air pollution..$^{80}$ A "standard of performance" is defined as a standard which "reflects the degree of emission limitation achievable through the application of the best system of emission reduction which (taking into account the cost of achieving such reduction) the Administrator determines has been adequately demonstrated." to mean that the Administrator is required not only to take into account the economic costs of comphance by the industry but also any "counter-productive environmental effects" of a proposed standard. ${ }^{82}$

75. 486 F.2d 375 (D.C. Cir. 1973), petition for cert. filed, 42 U.S.L.W. 3388 (U.S. Jan. 8, 1974) (No. 73-1008).

76. 489 F.2d 1247 (D.C. Cir. 1973).

77. Portland Cement Ass'n v. Ruckelshaus, 486 F.2d 375, 386-87 (D.C. Cir. 1973); Environmental Defense Fund, Inc. v. EPA, 489 F.2d 1247, 1257 (D.C. Cir. 1973). See also Essex Chem. Corp. v. Ruckelshaus, 486 F.2d 427, 431 n.6 (D.C. Cir. 1973) cert. denied, 42 U.S.L.W. 3610 (U.S. Apr. 29, 1974).

78. Portland Cement Ass'n v. Ruckelshaus, 486 F.2d 375, 386 (D.C. Cir. 1973).

79. See notes 1-8 supra and accompanying text.

80. 42 U.S.C. \& $1857 \mathrm{c}-6$ (1970). See note 4 supra.

A "new source" is defined as a stationary source, the construction or modification of which commences after applicable regulations or proposed regulations are published. Id. $-6(\mathrm{a})(2)$. A "modification" is a physical change or a change in the method of operation of a stationary source which has the result of increasing the cmission of a pollutant or causing the emission of a new pollutant from that source. Id. -6(a)(4) (1970).

81. Id. $-6(\mathrm{a})(1)$ (emphasis added).

82. Portland Cement Ass'n v. Ruckelshaus, 486 F.2d 375, 385 (D.C. Cir. 1973); accord, Essex Chem. Corp. v. Ruckelshaus, 486 F.2d 427, 431 (D.C. Cir. 1973). In a footnote, the court in Portland Cement spells out its construction of the "best 
Accordingly, the District of Columbia Circuit interpreted section 111 as requiring the equivalent of a NEPA statement:

The [Clean Air] Act thus requires that the Administrator accompany a proposed standard with a statement of reasons that sets for [sic] the environmental considerations, pro and con, which have been taken into account as required by the Act, and fulfillment of this requirement is reviewable directly by this Court. ${ }^{83}$

The EPA was thus excused from formal, procedural compliance with NEPA within the context of what the court termed a narrow statutory exemption. ${ }^{84}$ One aspect of the Clean Air Act which, although not dispositive, was a "substantial consideration"ss in the court's analysis was the fact that the Act imposes precise time schedules for the promulgation of new sources standards. Section 111 directed the Administrator to publish a hist of categories of stationary sources within 90 days after December $31,1970 .{ }^{86}$ Within 120 days thereafter the Administrator was directed to propose standards of performance for each category named, and within an additional 90 days final regulations were to be promulgated. ${ }^{87}$ The court rejected the argument that section 111 could accommodate delay in the time alloted for the initial determination of categories of stationary sources until a NEPA statement could be prepared, finding that there was simply "no legal latitude available to delay the action [under the Clean Air Act]."

system of reduction": "The standard of the 'best system' is comprehensive, and we cannot imagine that Congress intended that 'best' could apply to a system which did more damage to water than it prevented to air." 486 F.2d at 386 n.42.

83. Portland Cement Ass'n v. Ruckelshaus, 486 F.2d 375, 385 (D.C. Cir. 1973).

84. Id. at 386-87.

85. Id. at 381 .

86. 42 U.S.C. $\$ 1857 \mathrm{c}-6(\mathrm{~b})(1)(\mathrm{A})(1970)$.

87. Id. $\$-6(\mathrm{~b})(1)(\mathrm{B})$.

88. 486 F.2d at 381 n.19. One commentator has rejected the argument that the time constraints of the Clean Air Act require an exemption from the applicability of NEPA:

But NEPA does not mandate any particular method or time period for comment. At the time Congress passed the [Clean Air] Act (December 31, 1970), the Council on Environmental Policy [sic] had only issued Interim Guidelines for the preparation of NEPA statements (see 1 ELR 46001). Those Guidelines did not mention any set period for the commenting process, the 90-day period appeared in the Final Guidelines, published April 23, 1971 (see ELR 46049). Therefore, it can not fairly be construed that Congress intended to oust NEPA from the Clean Air Act proceedings by setting impossibly tight deadlines. Comment, supra note 70 , at 10,017.

See also Yarrington, The National Environmental Policy Act, 4 BNA ENVIRONMENT REP.-Monograph No. 17, at 37 (1974).

Portland Cement points out that a speeded-up NEPA procedure, which would be necessitated by the strict time requirements, would affect the quality of NEPA statements: "A major difficulty with this approach is that it tends to result in a group of second-class impact statements, ascribed to time urgencies." 486 F.2d at 381 n.19. 
the development by the Portland Cement court of the concept of full functional compliance in large part represented an effort by the court to adhere to the clear deadlines established under the Clean Air Act for promulgation of air quality standards, while simultaneously vindicating, to the maximum extent possible in light of those deadlines, the objectives of NEPA.

In Environmental Defense Fund ${ }^{89}$ the District of Columbia Circuit approved the EPA's cancellation of DDT registrations pursuant to FIFRA upon a determination that, like agency regulatory action under section 111 of the Clean Air Act, the procedures followed under FIFRA laad provided the functional equivalent of a NEPA imvestigation. ${ }^{90}$ The court arrived at this conclusion by noting that the "explicit language" of FIFRA requires that pesticides be deregistered if they will be imjurious to man and his environment. ${ }^{91}$ The court further noted that many NEPA protections are offered by FIFRA proceedings masmuch as ample judicial review is available under FIFRA and the opportunity for public comment was afforded in the lengthy hearings that were lield by the EPA. ${ }^{92}$ The court therefore concluded that the substantive and procedural aspects of FIFRA provided for full consideration of environmental issues: "[A]ll of the five core NEPA issues were carefully considered . . . all received attention during the hearings and decision-making process." vironmental Defense Fund court did not identify any problem similar to that presented by the strict time requirements imposed upon the EPA by section 111 of the Clean Air Act in the Portland Cement case. ${ }^{04}$ In fact, the Administrator even delayed the effective date of his cancellation order for six months to provide DDT users an opportunity to become acquainted with alternative pesticides. ${ }^{95}$

While Environmental Defense Fund purports to follow directly Portland Cement's rationale of "functional compliance," it may repre-

The Portland Cement opinion expresses the belief that the functional equivalent approach would avoid the "straitjacket" which NEPA would impose upon the rigid time constraints of the Clean Air Act. Id. at 386 n.43.

89. See notes 1, 2, 9-13 supra and accompanying text.

90. See notes 11-13 supra and accompanying text.

91. 489 F.2d at 1256.

92. Id.

93. Id. See note 1 supra.

94. See notes 85-88 supra and accompanying text. It should be noted that, while the court ignored the issue, the Administrator is under some time constraints under FIFRA. He must issue his order within 90 days of the completion of hearings. 7 U.S.C. $\$ 1356$ (c) (1970). See note 130 infra and accompanying text.

95. 489 F.2d at 1250. 
sent a somewhat more broadly applicable exemption than that recognized in the Clean Air Act cases. Because the Environmental Defense Fund court, unlike the court in Portland Cement, was not forced by the deadlines of the Clean Air Act to abandon strict pro forma compliance with the requirements of NEPA, it may be read as standing for the broader proposition that NEPA is satisfied in any situation where there are "substantive and procedural standards" which "ensure full and adequate consideration of environmental issues."96

\section{SUGgested CONTOURS FOR THE EPA EXEMPTION}

\section{The Merits of a Broad Exemption}

Three circuits, the Third, Fourth, and Sixth, have gone even beyond the doctrine of functional equivalence created in Portland $\mathrm{Ce}$ ment and made broadly applicable in Environmental Defense Fund to hold that the EPA is not required to comply in any fashion with the requirements of NEPA when actimg in its regulatory capacity. ${ }^{97}$ Furthermore, neither the Portland Cement nor the Environmental Defense Fund court foreclosed the possibility of an exemption from NEPA for the EPA which is broader than the functional equivalent exception. ${ }^{98}$ In addition, it is clear that Congress could specifically exempt the EPA from compliance with NEPA as it did in the 1972 amendments to the FWPCA with respect to EPA regulation under that Act. ${ }^{99}$ There are policy arguments both for and agaimst such a blanket exemption for the EPA from NEPA. Reasons which have been advanced in support of a broad exemption mclude: (1) the fact that, while NEPA is designed to protect the environment, the EPA plays a special role with regard to this objective and must be free to carry out its own mandate, which may require expeditious action that would be frustrated by strict application of the procedural requirements of NEPA; $; 00$ (2) the danger that the opponents of environmental protection would use the impact statement requirement as a

96. Id. at 1257 .

97. See text accompanying note 74 supra.

98. Portland Cement Ass'n v. Ruckelshaus, 486 F.2d 375, $384-85$ (D.C. Cir. 1973); Environmental Defense Fund, Inc. v. EPA, 489 F.2d 1247 (D.C. Cir. 1973).

99. 33 U.S.C. $\$ 1371$ (c) (Supp. II 1972); see Portland Cement Ass'n v. Ruckelshaus, 486 F.2d 375, 382 (D.C. Cir. 1973); ANDERson 116-22. See notes 26-30 supra and accompanying text.

100. See Yarrington, supra note 88, at 36; Portland Cement Ass'n v. Ruckelshaus, 486 F.2d 375, 383-84 (D.C. Cir. 1973) (dictum). While not finding it necessary to resolve the issue on the basis of policy arguments, Portland Cement does provide a concise statement of policy arguments on both sides of the issue. Id. 
tactic of litigation and delay;:101 and (3) the heavy administrative burden of preparing impact statements, resulting in interruption and delay of agency processes. While this administrative burden is certainly shared by other federal agencies, it would fall more heavily upon the EPA, since practically all of its decisions have significant environmental impact. ${ }^{102}$ Several suggestions have been advanced to alleviate

101. Cf. ANDERSON 121.

102. While it is extremely difficult to estimate the additional manpower which would be required for the EPA to comply with NEPA, the EPA has undertaken such a study. U.S. Environmental Protection AgENCY, supra note 38. An EPA task force compiled estimates of the additional manpower required by NEPA for performance of each regulatory action presently engaged in by the EPA with the exception of actions taken pursuant to the FWPCA, which have been exempted by Congress. See notes 26-30 supra and accompanying text. The report also estimated the additional manpower which would be required to achieve some form of "intermediate" compliance with NEPA for each activity. The form of the "intermediate" compliance suggested was generally the issuance of an environmental "explanation," a procedure whicl the EPA has since formally adopted in lieu of issuing full-fledged environmental impact statements. See notes 38-46 supra and accompanying text. The task force estimates are as follows: (1) Setting of national ambient air quality standards: One to two actions per year are anticipated, witl little imcremental manpower likely to be required due to NEPA, unless the impact statements would have to include "considerable discussiou of environmental effects and cost/benefit balancing," in which case a $50 \%$ increase in man-years will be required. Two to twenty total additional man-years due to compliance with NEPA are estimated for this activity. Id. at 51. (2) Approval of state implementation plans: 275 actions per year are anticipated, with incremental manpower increases due to NEPA compliance estimated to be 27.5-137.5 man-years. The cost of environmental "explanations" for the same actions is estimated to require 13.75-82.5 man-years. Id. at 55. (3) Establishment of standards of performance for new stationary sources: ten actions were anticipated for fiscal year 1974 requiring fifteen to twenty additional man-years. The intermediate compliance selected for this activity is to undertake the analysis required by NEPA without filing the statement. Estimates for this approach were ten to fifteen additional man-years for fiscal 1974. Id. at 57-58. (4) Establishment of emission standards for hazardous air pollutants: one to three actions per year are anticipated, with 1.5-6.0 additional man-years estimated. One to six man-years are estimated for intermediate compliance. Id. at 60 . (5) Establishment of motor vehicle emission standards: one to five actions per year are anticipated, requiring one to ten man-years. Id. at 62-63. (6) Suspension of motor velicle emission standards: one action is estimated for fiscal year 1974. This would require an additional 2.25-8 man-years to prepare a "brief" impact stateinent. (Statutory time constraints do not permit preparation of a full impact statement. Id. at 6465). The intermediate compliance suggested would require more man-years (7.5-10) because the task force recommends performance of the type of analysis NEPA requires "on an ongoing basis." Id. at 66-67. (7) Pesticides registration: A total of 7,615 actions (registrations of new chemicals and uses, renewals, and amendments) are anticipated each year, requiring 101-530 man-years (assuming no multiple-action inpact statements). Id. at 70. The new pesticides act, 7 U.S.C.A. $\$ 136$ (Supp. 1974), requires publication of data supporting a decision and thus no additional manpower is anticipated for intermediate compliance. U.S. ENvironmental PRotrCTION AGENCY, supra at 70. (8) Cancellation or suspension of pesticides: Four cancellation proceedings involving a public hearing are anticipated per year, with an estimated four manyears increment for compliance with NEPA. Ten other cancellation/suspension ac- 
this burden of requiring the EPA to comply with NEPA, imcluding selective legislative relief where necessary;:103 preparation of impact statements in "tiers," the more important, 'general problems receiving more compreliensive treatment and the less important problems receiving only brief treatment; ${ }^{104}$ and preparation of composite statements covering multiple agency actions where the impact is sufficiently similar to warrant coinbimed treatment. ${ }^{105}$

Probably the strongest argument against a broad exemption of the EPA from NEPA's requirement of an environmental impact statement is that the EPA, in taking action to reduce one pollutant, miglit ignore the adverse consequences arising in connection with other forms of pollution. ${ }^{106}$ There is also the suggestion that although NEPA compliance is burdensome, it allows "for needed input by other federal agencies and simultaneously open[s] up the decision-making process to scrutiny by the public."107 The benefits of requiring such compliance with NEPA likewise extend to the courts since a NEPA statement provides a comprehensive agency record which allows effective review of agency decisions. ${ }^{108}$

In order to resolve the question of the entitlement of the EPA to a blanket exemption from NEPA, lowever, the analysis must focus upon whether the basic purpose of NEPA is consistent witl the mandate of the EPA. ${ }^{109}$ In circumstances where congressional imtent is unclear because the legislative history of an act is ambiguous, it is appropriate to consider the policies underlymg the legislation. ${ }^{110} \mathrm{Sec}-$

tions are expected per year, requiring twenty additional man-years. Id. at 72 . (9) Solid waste management guidelines: Two actions per year are estimated, which will require two to four man-years. Id. at 75. (10) General federal radiation guidance and generally applicable environmental radiation standards: No mcremental manpower requirements are anticipated. $I d$. at 76.

The course of action recommended to the agency by the task force was to seek legislative relief, to implement the spirit of NEPA to the extent practical and to maintain the position in the courts that NEPA does not legally apply to the agency's regulatory programs. Id. at 81 .

103. See 1973 DukE L.J. 347, 357-58, in 1972 Developments.

104. ANDERson 122. See also Comment, supra note 22, at 10,142.

105. 1973 DUKE L.J. 347, 358, in 1972 Developments.

106. See ANDERSON 118; Yarrington, supra note 88, at 36.

107. Portland Cement Ass'n v. Ruckelshaus, 486 F.2d 375, 384 (D.C. Cir. 1973); Yarrington, supra note 88, at 36.

108. See note 45 supra and accompanying text.

109. See Portland Cement Ass'n v. Ruckelshaus, 486 F.2d 375, 383 (D.C. Cir. 1973).

110. See United States v. Sisson, 399 U.S. 267, $297-98$ (1970); Portland Cement Ass'n v. Ruckelshaus, 486 F.2d 375,383 (D.C. Cir. 1973); District of Columbia v. Orleans, 406 F.2d 957, 958-59 (D.C. Cir. 1968). The District of Columbia Circuit had previously stated the proposition as follows: '[T]he 'plain meaning' doctrine has 
tion 102(2)(C) of NEPA was designed to "institutionalize" environmental decision-making:"11 "The apparent purpose of the 'detailed statement' is to aid in the agencies' own decision making process and to advise other imterested agencies and the public of the environmental consequences of planned federal action."112 This process involves a systematic approach to decision-making and requires a balanced weighing of costs and benefits toward the goal of reaching an optimal solution to a resource allocation or other problein confronting an agency. ${ }^{113}$ In order to satisfy its obligation under NEPA, an agency must take into account all the "costs" involved in a decision-not only economic cost but also cost in terms of environmental resources. ${ }^{114}$ If this mandate were applied to the EPA, it would require that the agency consider the effect eacli regnlatory action will liave on the total environment. Accordingly, the EPA would be prohibited froin protecting one feature of the environment to the unreasonable exclusion of others.

With this analysis of the NEPA impact statement requirement in mind, it is necessary to examine the unique role of the EPA and to consider whether its mission would be frustrated by imposing upon it the procedural requirements of NEPA. The formation of a single agency to watch over the environment resulted from a realization that "[d]espite its complexity, for pollution control purposes the environment must be perceived as a single, interrelated system."115 The mission of the EPA was stated to be the supervision of a "coordinated

always been subservient to a truly discernible legislative purpose however discerned, by equitable construction or recourse to legislative history." Id. at 959 (footnotes omitted).

111. See Farbstein, Implementation of the National Environmental Policy Act-A View After Three Years, 9 LEX ET ScIENTIA 42, 58 (1972). See also Hearings on Agriculture-Environmental and Consumer Protection Appropriations for 1974 Before the House Subcomm. on Agriculture-Environmental and Consumer Protection of the House Comm. on Appropriations, 93d Cong., 1st Sess., pt. 5, at 188 (1973): "Sonne observers have suggested that the true significance of NEPA is that it makes environmental considerations an integral part of the decision-making process of governinent."

112. Calvert Cliffs' Coordinating Comm., Inc. v. AEC, 449 F.2d 1109, 1114 (D.C. Cir. 1971).

113. Id. at 1113. See generally Note, Cost-Benefit Analysis and the National Environmental Policy Act of 1969, 24 STAN. L. REv. 1092 (1972).

114. Calvert Cliffs' Coordinating Comm., Inc. v. AEC, 449 F.2d 1109, 1113 (D.C. Cir. 1971). Questions have been raised concerning the capability of agencies to quantify and value environmental resources. Furthernore, it is not clear from the Calvert Cliffs opinion how agencies are to determine the relative importance to be assigned to the various factors involved in the balancing process. See ANDERSON 256-58; Note, supra note 113, at 1097 .

115. Message of the President, July 9, 1970, reprinted at 42 U.S.C. $\S 4321$ note, at 10,661 . 
attack" on the pollutants which threaten that system. ${ }^{116}$ Obviously, this role will be fulfilled only if the EPA carefully considers the impact of each of its regulatory decisions on the entire environmental system. That is, of course, precisely the protection offered by a NEPA statement. The question remains whether, given the identity of purpose between NEPA and the mission of the EPA, there is any need for actual procedural compliance with NEPA by the EPA. If there is any danger that the EPA will fail to comply with its own mandate, the argument for application of the procedural requirements of NEPA to the EPA is strengthened. In fact, this danger was illustrated in Anaconda Co. v. Ruckelshaus where the EPA took the position that it could not take imto account anything other than air purity in setting an ambient air quality standard. ${ }^{117}$ The EPA's contention that it could not even peek at alternatives ${ }^{118}$ was clearly at odds with its own basic mandate, which is to regard the environment as a single system. Thus, in situations where Congress has not created a statutory exemption or at least mandated a separate procedure for accomplishment of the cost-benefit analysis required by NEPA, the procedural protections of NEPA offer the only guarantee that the EPA will fulfill its complete function. This alone constitutes a sufficient reason to reject the argument that the EPA is entitled to a blanket exemption from NEPA. The question remains, however, whether the "functional equivalent" doctrine announced in Portland Cement and arguably made broadly applicable in Environmental Defense Fund represents a correct balancing of these policy concerns.

\section{The Validity of the Functional Equivalence Doctrine}

The "functional equivalent" exception to NEPA's impact statement requirement is subject to criticisin on some of the same policy grounds as those which have been advanced to dispute the argument for a blanket exemption of the EPA from NEPA. Full compliance with the procedures of NEPA mandates that the inquiry into the environmental impact of a proposed federal action be conducted in a

116. Id. The inechanisin for this approach was outlined in the President's Message: -Identify pollutants.

-Trace thein through the entire ecological chain, observing and recording changes in form as they occur.

-Determine the total exposure of man and his environment.

- Examine interactions annong forms of pollution.

-Identify where in the ecological chain interdiction would be nost appropriate. Id.

117. 352 F. Supp. 697, 710 (D. Colo. 1972). See notes 47-64 supra and acconpanying text for a full discussion of the Anaconda case.

118. Id. 
systematic fashion, with comment from the public and other agencies solicited specifically for the purpose of responding to a prelimmary position taken by the EPA on the environmental impact of its proposed action. ${ }^{119}$ Sucli an approach contrasts sharply with the ad hoc nature of the "functional equivalent" approach. Furthermore, where there is a departure from the procedures outlined in NEPA, the agency is not required to consider or set out for scrutiny by the public, other agencies, or Congress those alternative means of achieving the same agency goals which are outside the administrator's sole authority to implement. ${ }^{120}$ Fmally, agencies other than the EPA have not been excused from strict procedural compliance witl NEPA merely because agency procedures provide for the equivalent in substance to a NEPA statement. ${ }^{121}$ In light of these considerations the validity of the functional equivalent exception to NEPA's impact statement requirement would seem to be open to challenge.

\section{The Statutory Conflict Doctrine}

There is, lowever, another line of analysis that could be used to justify the specific exemptions in Portland Cement and Environmental Defense Fund. This approach focuses upon the language in section 102(2)(C) of NEPA which requires compliance "to the fullest extent possible."122 While this passage has largely been iguored by the cases considering the applicability of NEPA to the EPA, it las been interpreted in a number of other NEPA cases, most notably Calvert Cliffs' Coordinating Committee, Inc. v. AEC. ${ }^{128}$ That case limited the potential scope of this exception to NEPA by stating that the provision was not to be used to permit NEPA to become a "paper tiger."124 Rather, the requirement sets a high standard for the agencies: "Section 102 duties are not inherently flexible. They must be complied with to the fullest extent, unless there is a clear conflict of statutory authority." ${ }^{25}$ Applying this interpretation to the

119. See ANDERSON 120.

120. Id. at 120-21.

121. See, e.g., Natural Resources Defense Council, Inc. v. Grant, 341 F. Supp. 356, 365-66 (E.D.N.C. 1972).

122. 42 U.S.C. $\$ 4332$ (1970) (emphasis added).

123. 449 F.2d 1109 (D.C. Cir. 1971).

124. Id. at 1114 .

125. Id. at 1115 (emphasis added). Section 104 of NEPA, 42 U.S.C. $\$ 4334$ (1970), provides that nothing in section 102 shall in any way affect the specific statutory obligations of any federal agency

(1) to comply with criteria or standards of environmental quality, (2) to coordinate or consult with any other Federal or State agency, or (3) to act, or refrain froin acting contingent upon the recommendations or certification 
instant problem, the proper path for developing the role of the EPA within the mandate of NEPA would be to examine the EPA's specific statutory function on a program-by-program basis. Where there is a clear statutory conflict, explicit or implicit, the EPA would qualify for an exemption from strict procedural compliance. ${ }^{128}$ Under this analysis, where an EPA statutory duty requires a departure from full compliance, the language of NEPA which requires compliance "to the fullest extent possible" would provide for an exemption. ${ }^{127}$

\section{CONCLUSTON}

Application of this statutory-conflict approach in Portland Cement and Environmental Defense Fund would have enabled the courts in those cases to reach the same result as was reached under the "functional equivalence" approach, thus giving substantial weight to the total environmental as well as economic and social impact of the standards under consideration, but would have reached this result through an approach of nore certain legal validity than the functional equivalence doctrine. ${ }^{128}$ For example, in Portland Cement a statutory conflict could seem to have clearly existed in that it would almost certainly have been impossible for the EPA Administrator to comply with the time constraints of section 111 of the Clean Air Act and also fully comply with the procedures of NEPA governing the issuance of an environmental impact statement. ${ }^{129}$ It seems quite

of any other Federal or State agency.

Calvert Cliffs" concludes that "[o]nly when such specific obligatious conflict with NEPA do agencies have a right under $\$ 104$ and the 'fullest extent possible' language to dilute their compliance with the full letter and spirit of the Act." 449 F.2d at 1115 n.12.

126. The term "implicit exemption" is intended to apply to those circumstances where a statutory requirement inakes full compliance impossible. See 115 CoNG. REC. 40,417-18 (1969); Calvert Cliffs' Coordinating Comm., Inc. v. AEC, 449 F.2d 1109, 1114 (D.C. Cir. 1971); CEQ GuDblInEs $\$ 4,38$ Fed. Reg. 20,550 (1973).

127. The Portland Cement court noted that one difficulty with this approach is that it by necessity gives rise to an inferior class of impact statements. 486 F.2d 375,381 n.19 (D.C. Cir. 1973). See note 88 supra.

128. See notes 119-21 supra and accompanying text.

129. Cf. Portland Ceinent Ass'n v. Ruckelshaus, 486 F.2d 375, 380-81 (D.C. Cir. 1973). See notes 85-88 supra and accompanying text. See U.S. ENVIRoNmental ProTECTION AGENCY, supra note 38, at 37.

Frederick Anderson of the Environmental Law Institute takes the position that new, strict statutory deadlines should not automatically excuse the agency from compliance with NEPA. He offers three suggestions as to how the conflict nay be resolved:

[T] the event incompatibility appears to exist, either the nore specific regulatory legislation in fact governs, guidelines specifying incompatible objectives may be rewritten to accommodate coinphiance with both acts, or EPA may be asked to make a special effort to move the administrative process more rapidly than it might like in order to comply. ANDERSON 119. 
likely that more time would have been required for the Administrator to have prepared a detailed impact statement, circulated it to other agencies for comment, and assessed those comments, than he would have been allowed under section 111's deadlines for the setting of air quality standards. But rather than merely finding compliance upon the satisfaction by the EPA of some rather arbitrarily defined degree of functional compliance with NEPA as did the court in Portland Cement, the preferable approach in that case would seem to have been demanding the fullest possible adherence to the requirements of NEPA, consistent with full compliance with the Clean Air Act-a statute expressly directing that a particular environmental responsibility be carried out by a designated environmental agency in a congressionally specified manner-whether or not the resulting compliance with the more generally applicable requirements of NEPA constituted the "functional equivalent" of an impact statement. Similarly, this "statutory-conflict" analysis would arguably have resulted in a more nearly correct balancing of the specific objectives of FIFRA and those of NEPA in the Environmental Defense Fund case, had it been used in lieu of a merely ad hoc determination by the court that substantive and procedural requirements of FIFRA constitute the "functional equivalent" of an environmental impact statement. If the court had applied the "statutory-conflict" analysis, it could have concluded that a number of specific objectives of FIFRA may well have been sacrificed by the requirement of an environmental impact statement in that case. For example, although the court made no mention of the fact, under FIFRA the EPA Administrator is specifically required to issue his order regarding cancellation or registration of a pesticide within ninety days of the hearing required under the Act, ${ }^{130}$ a time period of sufficient brevity that in some cases it might not be possible for the Administrator to compile the detailed impact statement demanded by NEPA. ${ }^{131}$ Furthermore, several recent court decisions lave required that a federal agency file an impact statement prior to holding a public hearing on a proposed federal action significantly affecting the environment. ${ }^{132}$ If such a requirement were imposed on the EPA Administrator when moving to register or cancel the registration of a chemical under FIFRA, the EPA would itself be forced to gather the information necessary to evaluate the environmental im-

130. 7 U.S.C. $\S 135 b(c)(1970)$.

131. Cf. U.S. ENVIRonmental Protection Agency, supra note 38, at 71-72.

132. See, e.g., Greene County Planning Bd. v. FPC, 455 F.2d 412 (2d Cir.), cert. denied, 409 U.S. 849 (1972); Harlem Valley Transp. Ass'n v. Stafford, 360 F. Supp. 1057, 1065 (S.D.N.Y. 1973). 
pact of its proposed action. ${ }^{133}$ Such a development, stemming from enforcement of NEPA's impact statement requirement, would in iessence shift the burden of proof regarding the safety of chemicals from the registrant, on whom it is specifically placed by FIFRA, to the administrator. ${ }^{134}$

Where these specific environmental objectives under FIFRA come into conflict in this fashion with NEPA's more general requirement that federal agencies file an environmental impact statement for major federal actions significantly affecting the environment, it may be argued that the correct resolution is a "statutory-conflict" approach which fully vindicates the more specific congressional provision for protection of the environment, and then satisfies the more general requirements of NEPA "to the fullest extent possible" in light of the necessity of giving priority to the more specific environmental protection provision. It is submitted that this approach is clearly preferable to that followed by the three circuit courts which, by giving the EPA a blanket exemption from NEPA's impact statement requirement, placed no weight on the broader environmental concerns of NEPA, and that it is also superior to the approach of the Portland Cement and Environmental Defense Fund courts which gave these concerns only slightly greater credence in their subjective determination that the Clean Air Act and FIFRA require the "functional equivalent" of an environmental impact statement.

133. U.S. ENVIRoNMENTAL Protection AGENCY, supra note 38, at 71.

134. Continental Chemiste Corp. v. Ruckelshaus, 461 F.2d 331, 335 (7th Cir. 1972); Stearns Elec. Paste Co. v. EPA, 461 F.2d 293, 304-05 (7th Cir. 1972); U.S. Environmental Protection Agency, supra note 38, at 71. 